a man of athletic frame can "run himself out" to such an extent that he requires Io litres of oxygen at the end of exercise above his resting consumption, he will absorb this amount during the 8-10 minutes which follow the end of the exercise. Now the amount of lactic acid which this oxygen will oxidise can be calculated, and on the assumption that a man of $70 \mathrm{kgm}$. weight is using $25 \mathrm{kgm}$. of muscle, the calculation indicates that when an athletic man is exhausted, the lactic acid present will amount to 0.33 per cent. of his muscle weight. But Meyerhof has determined that the maximum percentage of lactic acid which can be produced by stimulation in isolated mammalian muscle varies from 0.3 to 0.4 per cent. The agreement between the two figures is very striking.

The fact that a runner does not consume all the oxygen he requires for running until the exercise is over may be regarded in another light. One may say that the runner gets credit for oxygen. Let us suppose that before exhaustion he can get credit for ro litres. Then, if during exercise he breathes in 5 litres per minute, it follows that in running for I minute he has energy corresponding to I $_{5}$ litres of oxygen at his disposal. In running for 5 minutes, however, the energy available only corresponds to $(x 0+5 \times 5=) 35$ litres of oxygen; that is to say, it corresponds to 7 litres per minute. Roughly speaking, the energy available per minute when running 5 minutes is less than half that available when running only I minute.

It was found to be possible to plot a curve showing the relation of the true oxygen consumption in running various distances at a maximum rate to the time taken. The distances chosen were those of the customary flat races. It was found that the curve was of the same general type as that obtained when the speed developed in the various world's records was plotted against the time taken. In other words, it was evident that the shape of this latter curve could have been predicted from considerations of oxygen consumption.

\title{
The Fiftieth Anniversary of the Dutch Zoological Society.
}

THE fiftieth anniversary of the foundation of the Nederlandsche Dierkundige Vereeniging, which was celebrated at Amsterdam on September 24 and 25, was an event of much scientific interest.

At the meeting held in the large hall of the Amsterdam Zoological Gardens ("Natura magistra Artis") the president, Prof. J. F. van Bemmelen, of the University of Groningen, delivered an interesting address on the history of the Society. He referred in the course of his address to the important part the Society has played in the scientific investigation of the Dutch marine fauna and flora and in the establishment of the permanent Marine Biological Station at Helder, to the activity it has shown in the movements for the preservation and protection of native wild animals and to its association, in an advisory capacity, with Dutch Government Departments on questions concerning the scientific development and regulation of the marine and fresh-water fisheries.

At the conclusion of his address the following were admitted Honorary Members of the Society: Prof. O. Abel, Vienna; Prof. M. Caullery, Paris; Prof. L. Dollo, Brussels; Prof. B. Grassi, Rome ; Prof. V. Häcker, Halle; Prof. S. J. Hickson, Manchester ; Prof. N. Holmgren, Stockholm.; Prof. T. H. Morgan, New York; Dr. F. Sarasin, Basle; Dr. J. Schmidt, Copenhagen.

On the following day, September 25, a large party of the members with their foreign guests set forth from Amsterdam in a steamboat through some of the most interesting and beautiful waterways of that part of the country to visit the new Fresh-water Biological Laboratory stationed in the river Vecht near Vreeland. A large and commodious houseboat called the Meevval has been fitted up with aquaria, dredging apparatus and other appliances for systematic and biometrical investigations of the fresh-water fauna, and there is sleeping accommodation for two or three investigators and the staff. The Meerval can be moved about from place to place during the summer months and is laid up for the winter at Helder.

The party was received on board the Meerval by Dr. Redeke, the director of the Marine Biological Station and Inspector of Fisheries, who gave an account of the investigations in progress and explained the exhibits and apparatus that were displayed.

One important result of the activities of Dr. Redeke and his assistants will be the publication of periodical reports on the fauna and flora of the Zuider Zee, and particularly of that part of it which is threatened with destruction by draining. An advanced copy of the first number of these reports was shown to the visitors.

The members of the society and their guests were entertained on the Sunday night at a banquet in Amsterdam, and on the Monday were the guests of Dr. and Mrs. Redeke at lunch at Vreeland.

It was unfortunate that Prof. Caullery (Paris), Prof. Dollo (Brussels), Prof. Grassi (Rome), Prof. Morgan (New York), and Dr. Schmidt (Copenhagen) were unable to attend the celebrations; but the foreign guests who were present thoroughly enjoyed the opportunity thus given to them by their most hospitable Dutch hosts of an interchange of views on zoological problems with friends and colleagues thev had not met since pre-war days.

We may congratulate the Dutch Zoological Society on the attainment of its fiftieth anniversary, and on the valuable scientific work it has accomplished since its foundation.

\section{Processes of Rock-Formation.}

$\mathrm{N}$ a long communication sent to us by $\mathrm{Mr}$. J. $\mathrm{H}$. Goodchild, dealing with the distribution of sodium and calcium, reference is made to Prof. J. Joly's calculation of the age of the earth from the saltness of the sea, a calculation based on the assumption that the salt in the sea has been carried there by streams and rivers and has been derived by solution from the land. In opposition to this view Mr. Goodchild suggests that, contrary to the notions held at the present day by geologists, salts pass from the ocean to the land, and are being fixed as new mineral combinations in the rocks through which they percolate. He regards sedimentary rocks, such as sandstone and shale, as unstable, and liable to admixture with one another as well as to modification by the action of soluble substances like salt and calcium carbonate. As examples of changes of this sort he points to the dolomitisation of limestone, the

NO. 2765 , VOL. I IO] 